\title{
Determinants of latrine utilization in Munggur Village, Mojogedang District, Karanganyar Regency, Central Java
}

\author{
Nurjazuli Nurjazuli $^{1 *}$, Tri Joko ${ }^{1}$, Anggi Bela Saputri ${ }^{2}$ \\ ${ }^{1}$ Department of Environmental Health, Faculty of Public Health Diponegoro University, Semarang \\ ${ }^{2}$ Student of Undergraduate Program, Faculty of Public Health Diponegoro University, Semarang
}

\begin{abstract}
The use of latrines by the community will affect the incidence of ducts, such as diarrhea. The Karanganyar Regency Government has built communal latrines to reduce open defecation, however is not yet optimal and there are still many open defecation communities (BABS). This study aims to examine the determinants of latrine utilization by the community. Observational research has been carried out with Cross-Sectional design. A total of 83 family heads from 578 populations were taken by proportional random sampling as research subjects. The variables examined in this study include knowledge, attitudes, latrine ownership, availability of clean water, support from community leaders and health workers, and latrine utilization. Data collection is done by interview and direct observation of research objects, with questionnaire instruments and observation sheets. Research data were analyzed by Chi-Square Test. As many as $18.1 \%$ of the people do not use latrines to defecate. Statistical analysis showed that there was a relationship between attitudes, latrine ownership, availability of clean water, and support from community leaders with the practice of using latrines in daily bowel movements with p-values of $<0.05$, respectively. This research concludes that the attitude of the community, latrine ownership, availability of clean water, and community support greatly influenced the practice of using latrines for defecation.
\end{abstract}

Keywords. Environment and behavior, latrines utilization, Karanganyar

\section{Background}

Environment-based illness and death rates are still a public health problem in Indonesia. The environment is one of the most dominant factors affecting the degree of public health. Environmental factors are the condition of settlements, workplaces, schools/public places, water, clean air, technology, education, social, and economy. While attitudes are reflected in daily habits, namely, diet, cleanliness, lifestyle, and attitudes toward health efforts.

\footnotetext{
*Corresponding author: nurjzl_fkmundip@yahoo.co.id
} 
Improved health status can be realized through the fulfillment of environmental health facilities (sanitation) accompanied by the creation of community behavior by defecating in the toilet facilities they have. In Indonesia, fulfilling access to sanitation (latrines) is part of the objectives of the Sustainable Development Goals (SDGs). In its implementation, sanitation development is still a challenge from the socio-cultural aspects. There are still some people who defecate openly (BABS) into rivers or open spaces (gardens). Based on the Johannesburg declaration put forward at the Millennium Development Goals (MDGs) in 2015 , it was agreed that efforts to reduce the proportion of the world's people who do not have access to basic sanitation become toilets by 2025. This agreement has also been approved by countries in the world including Indonesia.

Based on the Republic of Indonesia's Health profile, the percentage of households that have access to proper sanitation starting from access to clean water to the ownership of healthy latrines in 2018 has only reached $69.27 \%$. Central Java Province has, the figure has reached 74.04\%.[1] Karanganyar Regency is one of the regions in Central Java that has reached $102 \%$. For the work area of Puskesamas Mojogedang II, the sanitation facility ownership has reached 98\%[2]. However, the high number of sanitation facilities ownership has not been followed by the practice of defecating well. It is still found that some people have not used the latrine to defecate or do open defecation (BABS).

BABS behavior is a reflection of social problems that still need to be resolved because it is very influential in efforts to create community health degrees. This BABS practice can pollute the environment, cause odor, and spread various microbes that cause disease, one of which can cause diarrhea. In 2015, UNICEF stated that as many as 1.7 billion children aged under five in the world suffer from cases of diarrhea caused by the practice of open defecation. Around 300,000 die every year or more than 800 per day suffer from diarrheal diseases caused by poor water, sanitation, and hygiene. In Karanganyar Regency of 2018, the incidence of diarrhea was $10.5 \%$, while in the Mojogedang II Puskemas II 804 cases of underfive diarrhea occurred[3].

BABS free conditions in the community or often called ODF (Open Defecation Free) must be pursued. The Karanganyar Regency Government has built communal latrines, one of which is in Sidorejo Hamlet, Munggur Village, Mojogedang District, as many as 2 units for 150 residents to use[4]. But it has not shown optimal conditions in the use of these toilet facilities. BABS practice by not utilizing latrines is one of the habits that individuals have as a result of imitating the behavior of people around them. To change these habits, the head of the family has the most important role because it is considered to be able to influence individual members of the family and surrounding areas in carrying out daily life activities. In families with low socioeconomic conditions will be one factor that causes a lack of desire to make individual toilets. This is because the construction costs in making healthy latrines are relatively expensive. On the other hand, in families who already have latrines, there are still family members who defecate even though communal latrines are available[5]. Based on this description, this study was conducted to examine the several determinants that influence the use of latrines in defecation in Munggur Village, Mojogedang District, Karanganyar Regency.

\section{Method}

This research was conducted in Munggur Village, Mojogedang District, Karanganyar Regency, Central Java. A cross-sectional design has been chosen as an approach in data collection. The sample in this study was 83 households taken proportionally random sampling from 578 existing households. The independent variables studied included knowledge, attitudes, latrine ownership, availability of clean water, support from community leaders, and health workers, while the dependent variable in this study was the practice of 
using latrines. Data collection is done by interview using a questionnaire and observing objects using a checklist. Data analysis was performed descriptively and analytically using the Chi-Square test. This study has received ethical approval from the Health Research Ethics Committee of the Faculty of Public Health, Diponegoro University, Semarang with No: 76/EA/KEPK-FKM/2020.

\section{Results}

\subsection{Characteristics of respondents}

Most (81.9\%) respondents in this study were male, $79.5 \%$ were aged $31-59$ years, and $25.8 \%$ of them had a high school education. The results of this study found that as many as $16.9 \%$ of the people in the study location were still practicing open defecation. They do not take advantage of existing sanitation facilities in defecation even though there are communal toilets and private property. Respondents who have a habit of defecating in the toilet, generally their family members also defecate in the toilet. However, respondents who practiced open defecation, there were family members who used communal latrines in defecating.

\subsection{The results of interviews and observations of research variables}

Data collection in this study was conducted with the head of the family to obtain information on the level of knowledge and attitudes in using the toilet. Observation of facilities for the availability of sanitation is done by observing objects directly. The results of interviews and observations can be seen in Table 1.

Table 1. Level of Knowledge, Attitude, and Availability of sanitation facilities, Support for Community Guides and Health Staff in Latrine Utilization Practices

\begin{tabular}{|c|c|c|c|c|c|c|c|}
\hline \multirow{3}{*}{$\begin{array}{c}\text { Environmental and } \\
\text { behavioral } \\
\text { determinants }\end{array}$} & \multicolumn{5}{|c|}{ Latrine Utilization Practices } & \multirow{3}{*}{$\begin{array}{c}\text { Score } \\
\mathrm{p}\end{array}$} & \multirow{3}{*}{$\begin{array}{c}\mathrm{PR} \\
(95 \% \mathrm{CI})\end{array}$} \\
\hline & \multicolumn{2}{|c|}{ Not Utilizing } & \multicolumn{2}{|c|}{ Make use of } & \multirow[t]{2}{*}{ Total } & & \\
\hline & $\mathrm{n}$ & $\%$ & $\mathrm{n}$ & $\%$ & & & \\
\hline \multicolumn{8}{|l|}{ Knowledge level } \\
\hline $\mathrm{Bad}$ & 3 & 30 & 7 & 70 & 10 & .22 & 1.99 \\
\hline Good & 12 & 15.1 & 61 & $\begin{array}{r}84 \\
.9\end{array}$ & 73 & & $(0.67-5.93)$ \\
\hline \multicolumn{8}{|l|}{ Attitude } \\
\hline Bad & 9 & 32.1 & 19 & $\begin{array}{r}67 \\
.9\end{array}$ & 28 & 0.01 & 3.53 \\
\hline Good & 5 & 9.1 & 50 & $\begin{array}{l}90 \\
.9\end{array}$ & 55 & & $(1.31-9.55)$ \\
\hline \multicolumn{8}{|l|}{ Latrine Ownership } \\
\hline Do not have & 9 & 47.4 & 10 & $\begin{array}{l}52 \\
.6\end{array}$ & 19 & $\begin{array}{c}0,00 \\
0\end{array}$ & 6.06 \\
\hline Have & 5 & 7.8 & 59 & $\begin{array}{r}92 \\
.2\end{array}$ & 64 & & $(2.31-15.92)$ \\
\hline \multicolumn{8}{|l|}{$\begin{array}{l}\text { Availability of Clean } \\
\text { Water }\end{array}$} \\
\hline Not available & 6 & 54.5 & 5 & $\begin{array}{l}45 \\
.5\end{array}$ & 11 & $\begin{array}{c}0.00 \\
2\end{array}$ & $\begin{array}{c}4.91 \\
(2,10-11,45)\end{array}$ \\
\hline
\end{tabular}




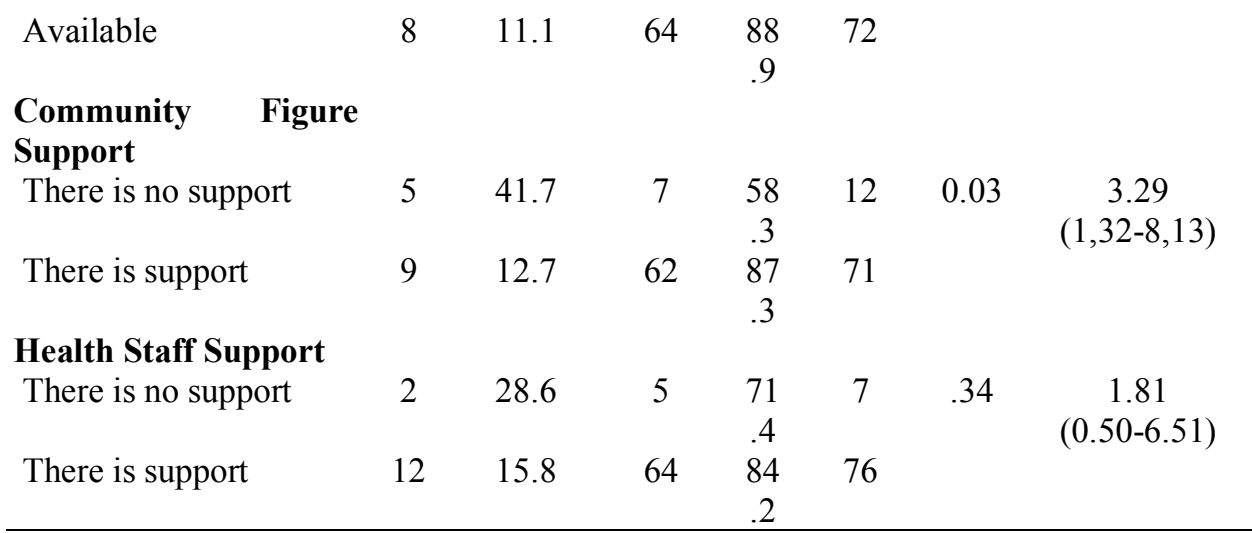

PR: Prevalence ratio

Table 1 shows that the majority of people $(81.9 \%)$ have used latrines for defecation, the greater than those not using latrines $(18.1 \%)$. Associated with the aspect of knowledge, in a group of people whose knowledge is poor, only a small proportion of them (30\%) do not use latrines to defecate. However, in the community group with good knowledge, a small portion of them $(15.1 \%)$ also do not use latrines to defecate. Thus, there is a phenomenon that shows that there is no difference in the practice of using latrines for defecation between community groups with good and bad knowledge. Although the proportion of people not using latrines in communities with poor knowledge is 1.9 times greater than in the community groups with good knowledge. This phenomenon is supported by the results of statistical analysis with a $\mathrm{p}$-value of 0.22 , which means there is no relationship between knowledge and the practice of using latrines for defecating in the community at the study site.

The attitude of the community as one of the factors that are driving the intensity of the practice of toilet use in defecation. The results of this study indicate that in the community group whose attitude is bad, as many as $32.1 \%$ of them do not use latrines to defecate. In the community group with a good attitude, only $9.1 \%$ of those who did not use the toilet in defecating. The proportion of people not using latrines for defecating in poor community groups is 3.5 times greater than in the community groups with a good attitude. The statistical test results obtained p-value 0.01 , meaning that there is a relationship between attitude and the practice of using latrines in defecation in the community at the study site.

The latrine ownership and clean water supply factors are the environmental factors examined in this study. The results of this study indicate that in the community group that does not have a toilet, as many as $47.4 \%$ of them do not use the toilet for defecation. A proportion of 6 times greater when compared to community groups who have latrines and do not use them for defecation $(7.8 \%)$. The statistical analysis results obtained a p-value of 0,000 , meaning that there is a relationship between latrine ownership in the family and the practice of using a latrine to defecate in the community at the study site.

The availability of clean water is complementary to toilet ownership. The results of this study indicate that the majority $(54.5 \%)$ of the community group that does not have clean water facilities do not use latrines to defecate. This proportion is 4.9 times greater than the community group that has clean water facilities $(11.1 \%)$. The statistical test results obtained p-value 0.002 , meaning that there is a relationship between the availability of clean water in the family with the practice of using latrines to defecating in the community at the study site.

Information on the support of community leaders in using latrines shows that as many as $41.5 \%$ of community groups who do not have the support of community leaders do not use latrines to defecate. This proportion is 3 times greater than the community groups that have the support of community leaders. The statistical test results obtained p-value 0.03 , meaning that there is a relationship between the support of community leaders with the practice of 
using latrines for defecation in the community at the study site. This phenomenon does not occur in people who get support from health workers. Community groups that do not have the support of health workers, as many as $28.6 \%$ of them do not use the toilet for defecation. This proportion is only 1,8 times greater than the community group that has the support of Health workers $(15 \%)$. The statistical test results obtained a p-value of 0.34 , meaning that there is no relationship between the support of health workers with the practice of utilizing latrines in the community at the study site.

\subsection{Discussion}

The results of this study found as many as $18.1 \%$ of the people did not use the toilet for defecation. This number is the best compared to general conditions in Indonesia which state as many as $44.8 \%$ of people do not use latrines for defecation [6]. The results of research in India showed conditions that are almost the same as the results of this study. As many as $18 \%$ of people are open defecation because they do not have a toilet [7]. The observations in the field show that the majority of people do not use latrines because the place for working as farmers in the field is far from home and they do not have the desire to find the nearest communal latrine, so they defecate in the river, near the rice fields of the work. Some possibilities why the community is still defecating is not having a toilet, not understanding the negative impact of BABS, or living habits that exist and are still developing in the community. Other studies have found different causes why people do not have latrines, that are not having land $(86.27 \%)$ and $67.64 \%$ have no fees [8]. Other research also states that the low use of latrines is shown by the existence of people who defecate openly outside the home, the low altitude of the community towards the use of latrines. As the reason why they do that is because of the low knowledge of negative impacts on health, and working conditions that are outside the home [9].

Although the proportion of open defecation is not large, this condition remains a public health problem. This is because BABS activity will be a source of transmission and spread of various germs, especially digestive tract diseases. Defending BABS impacts is very important to change the behavior of the community in using latrines. This understanding will also increase community participation in trying to have healthy latrines as a means of defecating. Statistical analysis shows that there is no relationship between knowledge and latrine utilization practices. However, that does not mean knowledge is not important concerning the community to use the latrine. As stated by Hamzah, the use of latrines, such as using latrines in the case of defecation to create good environmental health conditions [10]. So that, knowledge is still important because Laeli's research shows the results reveal that knowledge is significantly related to the use of latrines in Jatibarang Brebes with a pvalue of 0.014 [11].

On the other hand, knowledge is an aspect that will shape a person's attitude towards the phenomenon at hand. This attitude will encourage someone to act based on their desired interests. The results of this study indicate that as many as $32.1 \%$ of people who have bad attitudes do not use latrines to defecate. This attitude can have an impact on the low awareness of the community to defecate existing latrines both private and communal latrines. This was also corroborated by the results of statistical analysis with a p-value of 0.01 and a Prevalence Ratio (PR) of 3.53 (CI 95\%: 1.31-9.55). This means that people who have a bad attitude have the opportunity not to use the toilet to defecate 3.5 times greater than people who have a good attitude. For this reason, education efforts must continue to be encouraged to strengthen community attitudes to support the use of latrines in defecation. This effort is very important and relevant to the results of research that recommends continuing to encourage efforts on how to change people's attitudes to use latrines in daily life [6]. Attitude is a reaction or response of someone who is still closed to a particular stimulus or object, which already 
involves the opinion and emotions involved. So, the attitude involves thoughts, feelings, attention, and other mental symptoms. Changing habits is something that looks simply, but is very difficult to change, especially when a habit has changed a comfort. This is supported by Linda's research, which states that there is a significant relationship between attitude and behavior of the head of the family in utilizing latrines with values of PR 3.6 [12].

BABS is one of a variety of health problems that need priority in handling it. The provision of facilities for disposal of feces or latrines and the availability of clean water are the main prerequisites of the community to create a clean and healthy lifestyle. The results of this study found as many as $47.4 \%$ of the community groups who did not have toilet facilities did not use communal latrines to defecate. Unlike the community groups that have latrines, only $7.8 \%$ of them do not use latrines to defecate. This means that there are still some people who defecate even though they already have a toilet. According to Notoadmojo, the reason for the community not having a toilet is not because of economic factors, but rather because of the lack of public awareness about PHBS. In addition, another factor is community dependence on government assistance in the construction of latrines.[13] The results of this study indicate there is a relationship between latrine ownership and latrine use practices. This is relevant to Linda's research, which states that there is a relationship between latrine ownership and latrine utilization behavior in the Tambak Lorok Fishermen Settlement Area Semarang dengan $\mathrm{p}=0.001$ [14].

Based on table 1, the results of statistical analysis show that there is a relationship between the availability of clean water and the use of latrines for defecation with a p-value of 0.002 . This means that the availability of clean water is needed to support the community to use the toilet for defecation. People who have the availability of clean water have the opportunity to use the toilet for defecation as much as 4.9 times. There is relevance to the results of Anggoro's research which states that there is a significant relationship between the availability of clean water and the use of latrines. This becomes very logical because water is needed to flush dirt into a shelter or septic tank, so as not to disturb the aesthetics and unwanted odors. The availability of clean water supports comfort in using the toilet [15]. Other research in Bali also states that the importance of using clean water is associated with the occurrence of diarrhea in children. Although the results of the statistical analysis do not show a significant relationship, because the incidence of diarrhea is multifactor [16].

From the previous description, the researchers assume that people who do not have clean water availability will tend not to use latrines to defecate. Because water facilities are needed to clean the latrine each user finishes their hajad. Therefore, it is recommended that the local government increase access to clean water through the PDAM pipeline or non-pipeline services, namely by utilizing groundwater.

Community figures as key people play an important role in changing understanding and behavior. Their role is models for community members so that their support is needed in encouraging people to behave in a clean and healthy life. The results of this study showed that $41.7 \%$ did not use latrines because they did not have the support of community leaders. The total number is relatively high. This fact is supported by the results of statistical tests that show a significant relationship. Therefore, the maximum role of community leaders in providing education and role models for the surrounding community is very important to always be improved. From the results of other studies, this relationship still often causes controversy. According to Linda's research which states that there is no relationship between the support of village officials, community leaders, and religious leaders with the behavior of the head of the family in using the toilet $(p=0.548)$. But theoretically, the support of community leaders takes a big role in behavior change. This is as stated by L.Green that community leaders are reinforcing factors or driving factors for behavior change in the community. Community leaders are enablers for the surrounding community, so the role of community leaders is highly expected in efforts to improve the level of health [17]. 
Health Officers are the primary source from which the community obtains information on health issues. The results of this study indicate that there is no relationship between the support of health workers with the use of latrines in bowel movements. Statistically, there is no difference in the use of latrines between groups of people who have the support of health workers and those who do not have the support of health workers. The results of this study are not relevant to Erlinawati's study which states that there is a significant relationship between the construction of latrine use by Public health center officers and family behavior in using latrines $(P R=4.5)$. Differences in research can occur due to different characteristics of respondents. Respondents in the Erlinawati study were mothers [18], while in this study is the head of the family. However, this does not mean the role of health workers is not important in changing people's behavior. The role of health workers is still important as Kartono's statement, that the function or role of health workers is to foster community participation to improve the ability to live healthily. In the case of using latrines, activities undertaken by health workers include providing regular counseling about the benefits and willingness of the community to own and use family toilets as a means of defecating [19].

\section{Conclusion}

As many as $81.9 \%$ of the people have used latrines for defecation in Munggur Village and as many as $18.1 \%$ of the community has not used latrines for defecation. The attitude of community care, ownership of latrines, availability of clean water, and support of community leaders are determinants of creating changes in community behavior to utilize latrines in defecation. The role of health workers needs to be continuously encouraged to provide education to increase the knowledge, understanding and awareness of the community to always behave in a clean and healthy life (PHBS).

\section{References}

[1] Kementerian Kesehatan Republik Indonesia. Data dan Informasi Profil Kesehatan Indonesia (2018).

[2] Dinas Kesehatan Kabupaten Karanganyar. Profil Kesehatan Kabupaten Karanganyar (2018).

[3] A. Horhoruw A, Widagdo L. Perilaku Kepala Keluarga dalam Menggunakan Jamban di Desa Tawiri Kecamatan Teluk Ambon Kota Ambon. J Promosi Kesehat Indones (2014), 9(2):226-37.

[4] Qudsiyah WA, Pujiati RS, Ningrum PT. Faktor-Faktor yang Berhubungan dengan Tingginya Angka Open Defecation (OD) di Kabupaten Jember (Studi di Desa Sumber Kalong Kecamatan Kalisat). e-Jurnal Pustaka Kesehat (2015), 3(2):362-9

[5] Idya S. Hubungan Lingkungan Sosial dengan Perilaku Buang Air Besar Sembarangan Masyarakat di Kelurahan Mandailing Kota Tebing Tinggi. Universitas Sumatera Utara (2018).

[6] V. Yulyani, D.N. Dina, D. Kurnia. Latrine use and associated factors among rural community in Indonesia. Malaysian Journal of Public Health Medicine (2019), 19(1): 143-151.

[7] Sheethal MP, Shashikantha SK. Across-sectional study on the coverage and utilization of sanitary latrine in rural field practice area of a tertiary care hospital in Southern Karnataka. Int J Community Med Public Health (2016), 3:1540-3. DOI: http://dx.doi.org/10.18203/2394-6040.ijcmph20161624.

[8] Venkateswarlu M. A study on open air defecation practices among the population above 6 years in rural field practice area of Santhiram Medical College, Nandyal, Kurnool 
dist, Andhra Pradesh. Int J Community Med Public Health (2019), 6:1901-7. DOI: http://dx.doi.org/10.18203/2394-6040.ijcmph20161624

[9] W. Godana, B. Mengistie. Exploring Barriers Related to the Use of Latrine and Health Impacts in Rural Kebeles of Dirashe District Southern Ethiopia: Implications for Community Lead Total Sanitations. Health Sci J (2017), 11(2): 492-6. DOI: 10.21767/1791-809X.1000492

[10] B. Hamzah , A. Arsin , J.Ansar. Hubungan Perilaku Hidup Bersih dan Sehat dengan Kejadian DIare Pada Balita Di Kecamatan Belawa Kabupaten Wajo. Universitas Hasanudin (2012).

[11] L. Apriyanti, B. Widjanarko, B. Laksono. Faktor-faktor yang Mempengaruhi Pemanfaatan Jamban Keluarga di Kecamatan Jatibarang Kabupaten Brebes. J Promosi Kesehat Indones. (2019), 14(1):1-14

[12] L.D. Kurniawati, R. Windraswara. Faktor-Faktor yang Berpengaruh terhadap Perilaku Kepala Keluarga dalam Pemanfaatan Jamban di Pemukiman Kampung Nelayan Tambaklorok Semarang Abstrak. Public Health Perspect J (2017), 2(1):72-9.

[13] S. Notoatmodjo. Promosi Kesehatan dan Perilaku Kesehatan. Jakarta: Rineka Cipta (2010).

[14] L. Kurniawati, R. Windraswara. Faktor-Faktor yang Berpengaruh terhadap Perilaku Kepala Keluarga dalam Pemanfaatan Jamban di Pemukiman Kampung Nelayan Tambaklorok Semarang. Abstrak. Public Heal Perspect J (2017), 2(1):72-9.

[15] F.F. Anggoro, P.T. Ningrum. Analisis Faktor yang Berhubungan dengan Pemanfaatan Jamban Di Kawasan Perkebunan Kopi (Analysis of Factors Associated with the Use of Toilets At Coffee Plantation Region ). e-Jurnal Pustaka Kesehat (2015), 3(1):171-8.

[16] S.R. Inderan, W. Weta. Correlation between clean and healthy lifestyle behavior of mother with the incident of diarrhea in toddlers at working area of Puskesmas I Negara, Jembrana - Bali. Intisari Sains Medis (2018), 9(3): 14-20. DOI: 10.1556/ism.v9i3.180.

[17] L. Green . Health Promotion Planning; an Educational and Environmental Approach. Institute of Health Promotion Research University of British Colombia (2000).

[18] E. Pane. Pengaruh Perilaku Keluarga terhadap Penggunaan Jamban. J Kesehat Masy Nas. (2009), 3(2):230-4.

[19] Kartono. Modul Peran Tokoh Masyarakat dalam Kesehatan (2008). 